\title{
Mercury, Cadmium and Lead Biogeochemistry in the Soil-Plant-Insect System in Huludao City
}

\author{
Zhong-Sheng Zhang $\cdot$ Xian-Guo Lu \\ Qi-Chao Wang $\cdot$ Dong-Mei Zheng
}

Received: 24 July 2008/ Accepted: 26 February 2009/Published online: 12 March 2009

(c) The Author(s) 2009. This article is published with open access at Springerlink.com

\begin{abstract}
Mercury, cadmium, and lead concentrations of ashed plants and insects samples were investigated and compared with those of soil to reveal their biogeochemical processes along food chains in Huludao City, Liaoning Province, China. Concentration factors of each fragments of the soil-plant-the herbivorous insect-the carnivorous insect food chain were $0.18,6.57$, and 7.88 for mercury; $6.82,2.01$, and 0.48 for cadmium; $1.47,2.24$, and 0.57 for lead, respectively. On the whole, mercury was the most largely biomagnified, but cadmium and lead were not greatly accumulated in the carnivorous insects as expected when the food chain extended to the secondary consumers. Results indicated that concentration factors depended on metals and insects species of food chains.
\end{abstract}

Keywords Mercury · Cadmium · Lead - Soil ·

Plants - Insects · Concentration factor · Biogeochemistry

Biological uptake, transport and transformation of metals play an important role in element geochemistry. In the past, concentration factors calculated by metal concentrations

Z.-S. Zhang · X.-G. Lu · Q.-C. Wang ( $₫)$

Key Laboratory of Wetland Ecology and Environment,

Northeast Institute of Geography and Agro ecology, CAS, Changchun, China

e-mail: zzslycn@163.com; zzslycn@neigae.ac.cn

\section{Z.-S. Zhang}

Graduate University of Chinese Academy of Sciences, Beijing, China

D.-M. Zheng

Key Laboratory of Environmental Engineering, Shenyang

University, Shenyang, China expressed on dry weight basis were widely used in studying heavy metal transport and enrichment between different environmental medias (Streit 1992; Hsu et al. 2006), but matrix differences of environmental medias were not considered. Soils are consist of kinds of minerals, but plants and organisms are made up of organic compounds, and it is unreasonable to directly calculate the concentration factors using ratios of metal concentrations of organisms on dry weight basis to those of soil. If the organisms are ashed, the matrix differences between soil and organisms would vanished, and the concentration factors calculated would be more reasonable. For example, metal concentrations of fly ash of coals were widely used to discuss element enrichment (Yudovich and Ketris 2005a, b). In the past, scientists of the Soviet Union investigated metal concentrations of ashed plants to discuss metal biogeochemical transport in soil-plant system.

Insects are the important part of the ecosystem and provide a significant source of protein for wildlife such as birds and small mammals. Insects with different feeding habits occupy different positions in food chains. It is reported that some insects accumulate large amount of metals in their bodies and result in physiological toxicity (Devkota and Schmidt 1999, 2000; HeliÖvaara and Väisänen 1990; Hsu et al. 2006; Pamela et al. 2007). Furthermore, heavy metals would be transported to organisms on the higher position from insects along food chains (Zheng et al. 2008).

In monitoring environmental heavy metal pollution, some predatory insects are used as bio-indicators because of their high abilities of accumulating metals from the ambient environment (Nummelin et al. 2007). Human activities would cause abnormity of the regional metal element geochemistry in soil. Metals in soil would firstly be absorbed by plants, and then assimilated by animals. 
However, few are known about metal biogeochemistry process along the terrestrial food chains (Michopoulos et al. 2005; Bargagli et al. 2007; Koretsky et al. 2007).

The study area, Huludao City, is located in the Liaoning Province, China and it is an important non-ferrous smelting and chemical industry area in northeast China. Wuli River and Cishan River are two main rivers in the city. In the past few decades, waste water contaminated with heavy metals has been discharged into the Wuli and Cishan River by a chlor-alkali plant and zinc smeltery, respectively. The Cishan River also has been impacted by the dry deposition of metal-contaminated particulate matter from the zinc smeltery. The primary objective of the present study is to study heavy metal accumulation in insects and their biogeochemical transport in the soil-plant-insect system.

\section{Materials and Methods}

In the present study, 12 sample sites were selected, of which most were on the grasslands close to the two river channels (Fig. 1). Seven insect species, Locusta migratoria manilensis, Acrida Chinensis, Holotrichia, Eligma narcissus larvas, mantis, spider and dragonfly, were collected by hand, euthanized with alcohol immediately, and then preserved in a refrigerator at $-4^{\circ} \mathrm{C}$ until used. Insects were dried to constant weight at $60^{\circ} \mathrm{C}$ in an oven before used. Four plants, Salix babylonica, Populus, Ulmus pumila, and Echinochloa crusgalli, were collected at the same sites and stored in polythene bags. The plant leaves were washed with deionised water to remove metals attached on the surface, dried at room temperature and preserved in polythene bags after being ground to a homogenous powder.
Soil samples were collected, dried at room temperature, and then ground to pass through an 80-mesh nylon sieve.

Total mercury concentrations of soil and plants were extracted following the method of $\mathrm{H}_{2} \mathrm{SO}_{4}-\mathrm{HNO}_{3}-\mathrm{V}_{2} \mathrm{O}_{5}$ (Liu et al. 2003). All forms of mercury in samples were converted to $\mathrm{Hg}^{2+}$, and then $\mathrm{Hg}^{2+}$ was reduced to elemental $\mathrm{Hg}$ by $20 \% \mathrm{SnCl}_{2}$ solution. Cold atomic absorption technique was used to determine the concentrations of total $\mathrm{Hg}$ with an $\mathrm{F} 732-\mathrm{V} \mathrm{Hg}$ detector with a detection limit of $5 \times 10^{-2} \mathrm{ng} / \mathrm{g}$. The insect samples were digested by the same method and analyzed by a Terkran-2600 CVAFS (Tekran Inc., Canada) with a detection limit of $5 \times 10^{-6} \mathrm{ng} / \mathrm{g}$ (Zheng et al. 2008).

Cadmium and lead concentrations of soil were extracted following the method of $\mathrm{HClO}_{4}-\mathrm{HNO}_{3}-\mathrm{HF}$ and determined with an ICPS; Cadmium and lead of plants and insects were digested with $\mathrm{HClO}_{4}-\mathrm{HNO}_{3}$, analyzed by an ICPS and an ICP-MS, respectively (Zheng et al. 2007).

Accuracy of the analytical method was evaluated by comparing the expected metal concentrations in certified reference materials with the measured values. Simultaneous performance of analytical blanks and standard reference (GBW08301, GBW07601) confirmed that the accuracy of method was within acceptable limits (Table 1). The average recoveries of mercury, cadmium and lead were $101.89 \%, 94.43 \%$, and $96.09 \%$, respectively.

Ash contents were determined following the method: plants and insects samples were weighed incinerated at $550^{\circ} \mathrm{C}$ for $3 \mathrm{~h}$ and then weighted the ash.

All metals would be depleted at high temperature during the incinerating process, so metal concentrations of ashed samples could not be directly measured and should be calculated as the following formula:

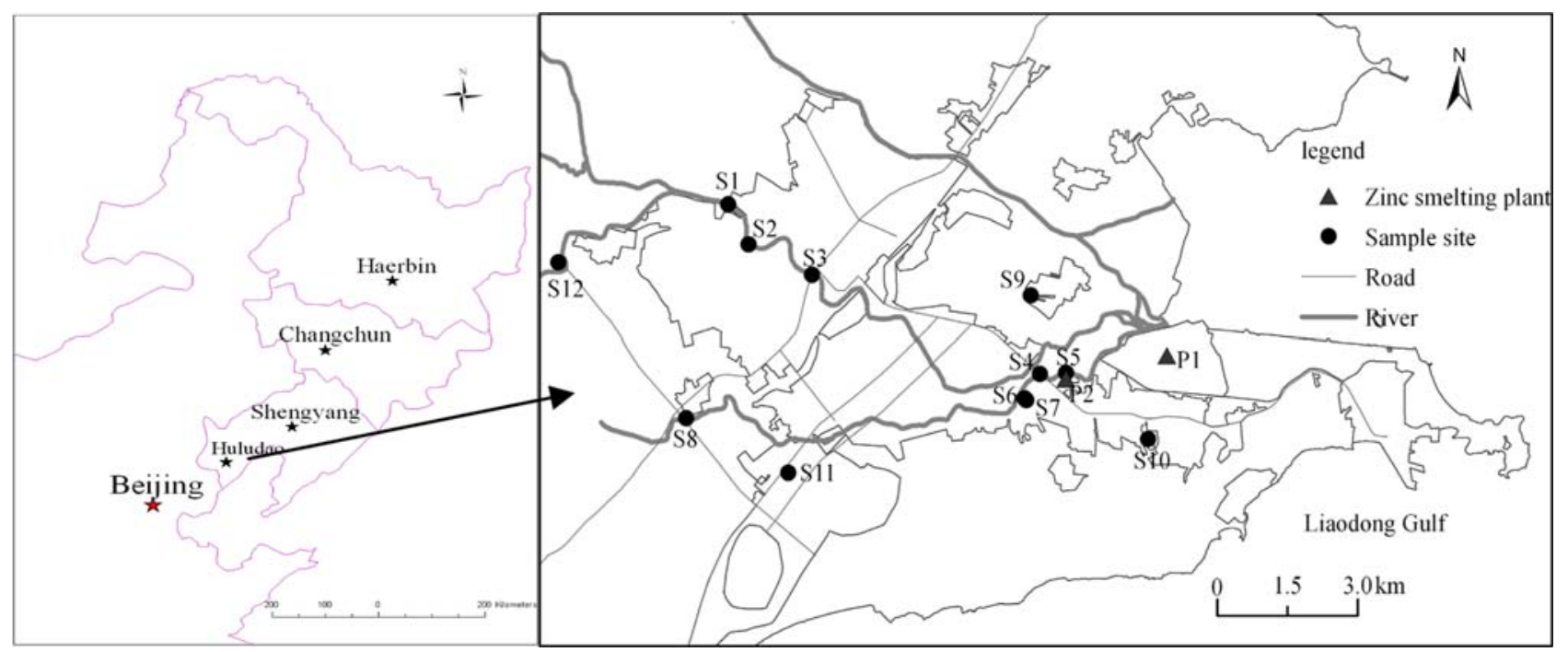

Fig. 1 Sample sites. $S$, Sample sites; $P$, pollution sources 
Table 1 Quality control (mean $\pm \mathrm{SD})(\mathrm{mg} / \mathrm{kg})$

\begin{tabular}{|c|c|c|c|c|c|c|}
\hline \multirow{2}{*}{$\begin{array}{l}\text { Certified reference } \\
\text { materials }\end{array}$} & \multicolumn{2}{|l|}{ Mercury } & \multicolumn{2}{|l|}{ Cadmium } & \multicolumn{2}{|l|}{ Lead } \\
\hline & $\begin{array}{l}\text { Expected } \\
\text { concentrations }\end{array}$ & $\begin{array}{l}\text { Measured } \\
\text { concentrations }\end{array}$ & $\begin{array}{l}\text { Expected } \\
\text { concentrations }\end{array}$ & $\begin{array}{l}\text { Measured } \\
\text { concentrations }\end{array}$ & $\begin{array}{l}\text { Expected } \\
\text { concentrations }\end{array}$ & $\begin{array}{l}\text { Measured } \\
\text { concentrations }\end{array}$ \\
\hline GBW08301 & $0.22 \pm 0.04$ & $0.21 \pm 0.02$ & $2.45 \pm 0.3$ & $2.40 \pm 0.2$ & $79 \pm 12$ & $80 \pm 9$ \\
\hline GBW07601 & $0.36 \pm 0.05$ & $0.39 \pm 0.01$ & $0.11 \pm 0.03$ & $0.10 \pm 0.01$ & $8.8 \pm 1.1$ & $8.03 \pm 0.48$ \\
\hline
\end{tabular}

$C_{\mathrm{ash}}=\frac{C_{\mathrm{dry}}}{1-W}$

where $C_{\text {ash }}$, the metal concentrations of ashes samples; $C_{\mathrm{dry}}$, the metal concentrations of dry samples; and the $W$, the ratios of ash weight to the dry sample.

All metal concentrations of plants and insects were $C_{\text {ash }}$ in the present work. SPSS10.0 for Windows and Excel 2003 were used for data analysis and ArcGIS 9.0 was used for map sample sites.

\section{Results and Discussion}

Metal concentrations of soil, plants and insects were showed in Table 2. The soil-plant-insect system was divided into three subsystems: soil-plant, plant-the herbivorous insect, and the herbivorous insect-the carnivorous insect.

In the soil-plant subsystem, mercury, cadmium and lead concentrations of soil were all higher than their corresponding local background values and 73, 149 and 18 times of their Clarke values in the curst, respectively. It indicated that soil here had been heavily polluted by heavy metals.
Average mercury, cadmium and lead concentrations of plants were $1.1,203.4$ and $325.3 \mathrm{mg} / \mathrm{kg}$, respectively, and varied greatly within plant species. It might be due to their distances to the pollution sources and different metal absorption abilities of plants.

The concentration factor $(\mathrm{CF})$ was applied to discuss the metal accumulation. If $\mathrm{CF}$ was over 1.0, metals were accumulated. In the present work, Cadmium and lead concentrations of plants were higher than their concentrations of soil and the concentration factors were 6.82 and 1.47, respectively, which indicated that cadmium and lead were in states of accumulation in plants and cadmium was the easiest metal transferring to plants from soil. Mercury was not accumulated in plants and its concentration factor was 0.18 .

Of the four herbivorous insects investigated, the highest metal concentrations were founded in Eligma narcissus larvas and the lowest in Locusta migratoria manilensis (Table 2). Mercury and lead concentrations significantly differed with species $(F=5.416, p=0.005 ; F=6.409$, $p=0.002$ ), but cadmium did not varied significantly with insect species $(F=1.616, p=0.212)$.

In the present study, Eligma narcissus larvas were collected from the Salix babylonica, Populus, Ulmus pumila;

Table 2 Heavy metal concentrations of soil, plants and insects $(\mathrm{mg} / \mathrm{kg})$

\begin{tabular}{|c|c|c|c|c|c|}
\hline Samples & Species & $\mathrm{n}$ & $\mathrm{Hg}$ & $\mathrm{Cd}$ & $\mathrm{Pb}$ \\
\hline Soils & $n=42$ & 42 & $5.83(4.32)$ & $29.82(24.32)$ & 221.1(127.6) \\
\hline \multirow[t]{4}{*}{ Plants } & Ulmus pumila & 9 & $2.29(2.41)$ & $51.89(45.68)$ & $179.7(156.5)$ \\
\hline & Populus & 4 & $0.41(0.32)$ & $259.9(243.5)$ & $160.9(136.8)$ \\
\hline & Salix babylonica & 7 & $0.26(0.19)$ & $405.6(367.6)$ & $722.6(648.9)$ \\
\hline & Echinochloa crusgalli & 12 & $1.31(0.88)$ & $96.0(77.6)$ & $238.0(221.4)$ \\
\hline \multirow[t]{4}{*}{ The herbivorous insects } & Eligma narcissus larvas & 168 & $12.91(9.90)$ & $575.6(727.5)$ & $1,243(1,179)$ \\
\hline & Holotrichia & 36 & $10.78(11.45)$ & $542.9(265.5)$ & $1,296(843)$ \\
\hline & Locusta migratoria manilensis & 71 & $0.62(0.60)$ & $103.2(208.8)$ & $60.13(69.59)$ \\
\hline & Acrida Chinensis & 62 & $3.77(2.94)$ & $410.8(524.2)$ & $312.3(339.2)$ \\
\hline \multirow[t]{3}{*}{ The carnivorous insects } & Spider & 65 & $0.92(1.30)$ & $313.4(345.1)$ & $116.0(175.9)$ \\
\hline & Mantis & 24 & $13.36(22.46)$ & 116.1(137.8) & $476.5(498.4)$ \\
\hline & Dragonfly & 33 & $151.7(180.8)$ & $153.9(167.5)$ & $662.9(695.2)$ \\
\hline Back ground values in soils ${ }^{\mathrm{a}}$ & & & 0.037 & 0.108 & 21.4 \\
\hline Clarke values in the curst & & & 0.08 & 0.2 & 12.5 \\
\hline
\end{tabular}

Standard deviations are given in parenthesis

a National Environmental Protection Agency of China (1990) 
all Holotrichia from the Ulmus pumila; both Locusta migratoria manilensis and Acrida Chinensis from grasslands, and so there were three food chains: foliages-Eligma narcissus larvas, Ulmus pumila-Holotrichia, and Echinochloa crusgalli-Locusta migratoria manilensis and Acrida Chinensisr.

Average mercury, cadmium and lead concentrations of foliages were $0.99,239.1$ and $354.4 \mathrm{mg} / \mathrm{kg}$, respectively. Concentration factors of mercury, cadmium and lead of the Eligma narcissus larvas to foliages were 13.09, 2.41 and 3.51 , respectively. Results showed that all metals could accumulate in Eligma narcissus larvas, of which mercury was with the highest concentration factor.

Average mercury, cadmium and lead concentrations of Holotrichia were slightly lower than those of Eligma narcissus larvas. In the Ulmus pumila-Holotrichia food chain, mercury, cadmium and lead were enriched 4.71, 10.46, and 7.21 times, respectively. Results showed that all metals were accumulated in the Holotrichia, of which cadmium was with the highest concentration factor.

Locusta migratoria manilensis and Acrida Chinensis are the representative common arthropods in grassland ecosystems. Their foods are Echinochloa crusgalli. Concentration factors of mercury, cadmium and lead of Locusta migratoria manilensis to Echinochloa crusgalli were 0.47, 1.07 and 0.25 , respectively. It concluded that mercury and lead were not and cadmium was slightly accumulated in Locusta migratoria manilensis. Concentration factors of mercury, cadmium and lead of Acrida Chinensis to Echinochloa crusgall were 2.88, 4.28 and 1.31, respectively. Results showed that Acrida Chinensis had larger metal absorption abilities than Locusta migratoria manilensis.

Three carnivorous insects were studied including spider, dragonfly and mantis. The highest mercury and lead concentrations were founded in dragonflies, and the highest cadmium concentrations in spiders (Table 2).

Spiders and mantis mainly feed on Locusta migratoria manilensis and Acrida Chinensis in summer grassland. Mercury, cadmium and lead concentrations of spiders were 1.48, 3.04 and 1.93 times of those of Locusta migratoria manilensis, respectively, but lower than those of Acrida Chinensis. Mercury, cadmium and lead concentrations of mantis were 21.55, 1.13 and 7.92 times of those of Locusta migratoria manilensis, respectively; 3.54, 0.28 and 1.53 times of those of Acrida Chinensis, respectively. It demonstrated that mantis accumulated metals more easily than spiders.

Concentration factors varied with metals and food chains (Table 3). In the soil-plants subsystem, lead was slightly and cadmium was the most strongly enriched but mercury was not so. In the plant-the herbivorous insect subsystem, all insects except Locusta migratoria manilensis could accumulate metals from their foods. In the
Table 3 Concentration factors in different terrestrial food chains

\begin{tabular}{lrrl}
\hline Food chains & $\mathrm{Hg}$ & $\mathrm{Cd}$ & $\mathrm{Pb}$ \\
\hline Soil-foliage & 0.17 & 8.02 & 1.6 \\
Foliage-Eligma narcissus larvas & 13.08 & 2.41 & 3.51 \\
Soil-Ulmus pumila & 0.39 & 1.74 & 0.81 \\
Ulmus pumila-Holotrichia & 4.71 & 10.46 & 7.21 \\
Soil-Echinochloa crusgalli & 0.22 & 3.22 & 1.08 \\
Echinochloa crusgalli-Locusta & 0.47 & 1.07 & 0.25 \\
$\quad$ migratoria manilensis & & & \\
Locusta migratoria manilensis-Spider & 1.48 & 3.04 & 1.93 \\
Locusta migratoria manilensis-Mantis & 21.55 & 1.13 & 7.92 \\
Echinochloa crusgalli-Acrida Chinensis & 2.88 & 4.28 & 1.31 \\
Acrida Chinensis-Spider & 0.24 & 0.76 & 0.37 \\
Acrida Chinensis-Mantis & 3.54 & 0.28 & 1.53 \\
\hline
\end{tabular}

Locusta migratoria manilensis-spider and mantis food chain, all metals were strongly accumulated by the carnivorous insects, but in the Acrida Chinensis- spider and mantis food chain, metals were not significantly accumulated. Results showed that heavy metals were not always enriched and biomagnified by the predators when food chains extended to the secondary consumers in terrestrial ecosystems.

On the whole, from soil to the carnivorous insects, metal concentrations were enriched with times of $0.18,6.57$, and 7.88 for mercury; $6.82,2.01$, and 0.48 times for cadmium; $1.47,2.24$, and 0.57 times for lead, respectively. Mercury was the most largely biomagnified, cadmium and lead were not greatly accumulated in the carnivorous insects as expected.

Compared with the aquatic food chains, concentration factors were lower in terrestrial ecosystems due to more complex components and structures of terrestrial food chains. In the present work, though concentration factors were discussed in terms of food chains. Metal concentrations of organisms were influenced by various factors and this was not considered in the research. For example, some insects would be on migration at their special stages and this would result in insects exposure to heavy metals inconstantly. The deficiencies in the work should be considered in the further studies.

The present study indicated that transfer and enrichment of heavy metals along the terrestrial food chains varied with metals and components of food chains. Heavy metal concentrations of insects were generally higher than those of plants, and it indicated that heavy metal could transfer to insects through foods. In the soil-plant-the primary consumers system, heavy metals were mostly biomagnified with the increasing of trophic levels, but it was not so when the food chain extended to secondary consumers. Mercury, cadmium, and lead had different concentration trends. It 
concluded that the transfer and enrichment of heavy metals along the terrestrial food chains were much more complex than the aquatic food chains.

Acknowledgments The research was funded by the National Natural Science Foundation of China (40830535) and the Innovation Foundation of Chinese Academy of Sciences (KZCX3-SW-437) and. Thank Mr. Shaoqing Zhang for help in sampling. The author appreciated Miss Wang for her suggestions.

Open Access This article is distributed under the terms of the Creative Commons Attribution Noncommercial License which permits any noncommercial use, distribution, and reproduction in any medium, provided the original author(s) and source are credited.

\section{References}

Bargagli R, Monaci F, Bucci C (2007) Environmental biogeochemistry of mercury in Antarctic ecosystems. Soil Biol Biogeochem 39:352-360. doi:10.1016/j.soilbio.2006.08.005

Devkota B, Schmidt GH (1999) Effects of heavy metals $\left(\mathrm{Hg}^{2+}, \mathrm{Cd}^{2+}\right.$, $\mathrm{Pb}^{2+}$ ) during the embryonic development of acridid grasshoppers (Insecta, Caelifera). Arch Environ Contam Toxicol 36:405414. doi:10.1007/PL00006613

Devkota B, Schmidt GH (2000) Accumulation of heavy metals in food plants and grasshopper form the Taigetos Mountains, Greece. Agric Ecosyst Environ 78:85-91. doi:10.1016/S01678809(99)00110-3

HeliÖvaara K, Väisänen R (1990) Concentrations of heavy metals in the food, faeces, adults, and empty cocoons of Neodiprion sertifer (Hymenopter, Diprionidae). Bull Environ Contam Toxicol 45:13-18. doi:10.1007/BF01701822

Hsu MJ, Selvaraj K, Agoramoorthy G (2006) Taiwan's industrial heavy metal pollution threatens terrestrial biota. Environ Pollut 143:327-334. doi:10.1016/j.envpol.2005.11.023
Koretsky CM, Haveman M, Beuving L, Cuellar A, Shattuck T, Wagner M (2007) Spatial variation of redox and trace metal geochemistry in a minerotrophic fen. Biogeochemistry 86:3362. doi:10.1007/s10533-007-9143-x

Liu RH, Wang QC, Lv XG, Fang FM, Wang Y (2003) Distribution and speciation of mercury in the peat bog of Xiaoxing'an Mountain, Northeastern China. Environ Pollut 124:36-46. doi: 10.1016/S0269-7491(02)00432-3

Michopoulos P, Baloutsos G, Economou A, Nikolis N, Aakeas EB, Thomaidis NS (2005) Biogeochemistry of lead in an urban forest in Athens, Greece. Biogeochemistry 73:345-357. doi:10.1007/ s10533-004-0359-8

National Environmental Protection Agency of China, Environmental Monitoring of China (1990) Element background values in soils of China. Chinese Environmental Sciences Publish, Beijing

Nummelin M, Lodenius M, Tulisalo E, Hirvonen H, Alanko T (2007) Predatory insects as bioindicators of heavy metal pollution. Environ Pollut 145:339-347. doi:10.1016/j.envpol.2006.03.002

Pamela F, Heckel TC, Keener (2007) Sex differences noted in mercury bioaccumulation in Magicicada cassini. Chemosphere 69:79-81. doi:10.1016/j.chemoshpere.2007.04.063

Streit B (1992) Bioaccumulation processes in ecosystems. Cell Mol Life Sci 48:955-970. doi:10.1007/BF01919142

Yudovich YE, Ketris MP (2005a) Mercury in coal: a review part 1 geochemistry. Int J Coal Geol 62:107-134. doi:10.1016/j.coal. 2004.11.002

Yudovich YE, Ketris MP (2005b) Arsenic in coal: a review. Int J Coal Geol 61:141-196. doi:10.1016/j.coal.2004.09.003

Zheng N, Wang QC, Zheng DM (2007) Health risk of Hg, Pb, Cd, Zn, and $\mathrm{Cu}$ to the inhabitants around Huludao Zinc Plant in China via consumption of vegetables. Sci Total Environ 283:81-89. doi:10.1016/j.scitotenv.2007.05.002

Zheng DM, Wang QC, Zhang ZS et al (2008) Bioaccumulation of total and methyl mercury by arthropods. Bull Environ Contam Toxicol 81:95-100. doi:10.1007/s00128-008-9393-x 